\title{
POLA KOMUNIKASI ANTAR BATAK MUSLIM DAN BATAK KRISTIANI DALAM MENINGKATKAN HARMONISASI BERAGAMADI KABUPATEN ASAHAN
}

\author{
Ismail Nasution \\ Program Studi Ilmu Komunikasi, Fakultas Dakwah dan Komunikasi \\ Universitas Islam Negeri Sumatera Utara \\ ismailnasution259@yahoo.com
}

\begin{abstract}
ABSTRAK
Tujuan penelitian ini untuk mengetahui pola komunikasi antar etnis batak Muslim dan Kristiani dalam meningkatkan harmonisasi beragama di Kabupaten Asahan , hambatan hambatan yang ditemukan oleh etnis batak Muslim dan Kristiani dalam meningkatkan harmonisasi beragama di Kabupaten Asahan, langkah langkah yang dilakukan oleh etnis batak Muslim dan batak Kritiani dalam meningkatkan harmonisasi beragama di Kabupaten Asaha, implikasi komunikasi etnis Batak Muslin dan Kristiani dalam meningkatkan harmonisasi beragama di Kabupaten Asahan. Penelitian ini dilaksanakan Kabupaten Asahan. Penelitian ini menggunakan pendekatan kualitatif dengan teknik pengumpulan data yaitu Wawancara mendalam, observasi, dan studi dokumen. Hasil penelitian ini menunjukkan bahwa pola komunikasi antar batak Muslim dengan batak Kristiani di Kabupaten Asahan untuk meningkatkan harmonisasi beragama dengan baik adalah dengan pola komunikasi interpersonal, pola komunikasi dialogis, pola komunikasi publik, pola komunikasi organisasi, Hambatan hambatan yang terjadi antar suku batak Muslim dan batak Kristiani di Kabupaten Asahan yaitu meningkatnya konsertvatisme keagamaan panatisme yang berlebihan pada pemeluk agama yang menimbulkan tidak ada ruang untuk menerima agama lain untuk hidup berdampingan, langkah langkah yang dilakukan oleh suku batak Muslim dan batak Kristiani yaitu saling menghormati dan menghargai sesame pemeluk agama, menumbuhkan komunikasi dan kesadaran rukun dan toleran antar batak Muslim dan batak Kristiani melalui pendidikan, sikap saling menghargai hak antar batak Muslim dan batak Kristiani dalam menjalani kehidupan beragama sehari hari, berfikir positif, sering melakukan dialog antar batak Muslim dan batak Kristiani, Implikasi komunikasi antar batak Muslim dan Batak Kristiani dalam meningkatkan harmonisasi beragama adalah saling menjalin keakraban, saling bekerja sama antar satu dengan yang lain, dan tidak adalagi upaya Kristenisasi dan Islamisai.
\end{abstract}

Kata Kunci: Komunikasi, Batak Muslim, Batak Kristiani, Harmonisasi 


\section{PENDAHULUAN}

Komunikasi sebagai bagian integral yang selalu iclude dan tidak bisa dipisahkan dari kehidupan manusia, tentunya menjadi satu aspek yang perlu diperhatikan dalam rangka mengatasi konflik sosial bernuansa agama. Dalam istilah hubungan lintas agama yang juga dimanajerial sebagai program pemerintah melalui berbagai kebijakannya, istilah komunikasi lintas agama ini lebih cenderung dikenal dengan istilah "dialog". Akan tetapi, istilah dialog untuk mewujudkan harmonisasi umat beragama yang komunikatif, meskipun cukup tepat, namun dirasa masih terlalu sempit. Sebab, istilah dialog mengandung makna adanya dua pihak yang dimediasi oleh pihak ketiga karena adanya problem-problem tertentu. Sementara itu, komunikasi memiliki makna yang lebih luas karena ia merupakan bagian integral dari diri seseorang sehingga karenanya dialog sangat membutuhkan komunikasi yang lebih sehat. Hal ini sebagaimana ditegaskan Habermas (1997:207) “dengan memahami komunikasi sebagai dimensi praksis manusia, teori tindakan komunikasi dapat memberikan landasan bagi terselenggaranya dialog antar umat beragama yang ideal, yang didasarkan pada rasionalitas komunikatif".

Meskipun Sumatera Utara memiliki tingkat keharmonisan bergama cukup kondisif, bahkan kondisi ini menjadi salah satu indikator yang menjadikan Sumatera Utara mendapatkan predikat "model kerukunan nasional", tetap saja potensi konflik banyak ditemukan didalamnya. Berdasarkan hasil dialog pengembangan wawasan multikultural antara pemuka agama, beberapa potensi konflik yang ditemukan di Sumatera Utara, adalah: (1) kesenjangan kesejahteraan sosial penduduk; (2) adakalanya terjadi intervensi terhadap tradisi dan keyakinan keagamaan yang bisa menimbulkan gesekan-gesekan sekalipun belum sempat berkembang; (3) kekerasan sosial akibat dari kesenjangan sosial maupun sikap budaya; (4) penggunaan idiom atau simbol-simbol secara tidak tepat yang telah menjadi identitas kelompok agama tertentu. Sementara itu, potensi kerukunan yang ditemukan di Sumatera Utara, adalah: (1) terbentuknya forum bersama antar umat beragama yang cukup efektif; (2) berfungsinya medium adat dan marga sebagai wadah yang berfungsi mengefektifkan komunikasi dan mempererat 
hubungan emosional serta tradisi antar umat berbeda agama; (3) keterlibatan pemuda dan tokoh agama dalam kamtibmas; (4) pencerahan pemahaman masyarakat melalui penerbitan bernuansa akademik; (5) tingkat rata-rata pendidikan penduduk yang relatif tinggi turut mempengaruhi kedewasaan berpikir masyarakat; (6) mudahnya komunikasi dan hubungan akrab antar pemuka agama; (7) koordinasi yang baik antar aparat dan pemuka agama; (8) kepekaan yang positif dari pemuka agama untuk mengantisipasi secara dini kemungkinan munculnya gangguan kerukunan umat beragama. Ridwan (2003:30)

Sihab (2005:80) mengatakan agama Islam dan Kristen di Indonesia, merupakan agama Samawi (revealed religion), yang meyakini terbentuk dari wahyu Ilahi Karena itu memiliki rasa superior, sebagai agama yang berasal dari Tuhan. Oleh karena itu kedua agama tersebut dituntut untuk damai dan harmonis dalam menjalankan ibadah dan aspek keagaamaan lainyya.

Suku batak di Kabupaten Asahan berdasarkan data statistik tahun 2008 diketahui bahwa dianggap menarik dijadikan sebagai objek penelitian karena keberadaannya terletak pada daerah yang berbasis suku melayu dan bisa dikatakan suku melayu tersebut menjadi suku asli Kabupaten Asahan. Kabupaten Asahan merupakan salah satu kabupaten di provinsi Sumatera Utara, yang mayoritas beragama Islam. oleh karenanya daerah ini berada pada kawasan etnis melayu pantai timur dengan tingkat perekonomian Masyarakat dan pendidikan yang masih rendah.

Akan tetapi keberadaan Suku Batak disana, tidak secara otomatis menunjukkan keharmonisan beragama tersebut, karena dalam kenyataannya suku batak yang menganut agama Islam dan suku batak yang menganut agama Kristen terlihat saling berkelompok kelompok dan sangat tidak tampak sekali sebagai salah satu etnis yang melakukan hubungan sosial dengan baik dan harmonis dikarenakan perbedaan agama tersebut.

Jika Komunikasi merupakan salah satu upaya dan tolak ukur yang sangat penting dalam keberhasilan untuk meningkatkan keharmonisan dalam beragama, maka peranan komunikasi dapat dianggap sebagai "lokomotif” yang untuk 
menopang terjadinya keharmonisan dalam beragama. Tentu saja pola komunikasi yang digunakan sangat memiliki peran yang cukup penting dalam pencapaian keberhasilan untuk meningkatkan keharmonisan dalam beragama antar satu etnis yang tinggal di Kabupaten Asahan.

Berdasarkan penegasan diatas, dapat dilihat bahwa komunikasi sangat penting dan berperan aktif sebagai faktor ekstrinsik untuk dapat menciptakan keharmonisan bagi umat beragama. Selain itu, pola komunikasi yang akan terjadi sesuai dengan langkah kerja yang benar akan menjadi faktor terwujudnya harmonisasi beragama.

Berdasarkan uraian dan latar belakang di atas, maka peneliti memfokuskan penelitian ini dengan beberapa point yaitu:

1. Pola komunikasi antar etnis batak Muslim dan Kristiani dalam meningkatkan harmonisasi beragama di Kabupaten Asahan

2. Hambatan hambatan yang ditemukan oleh etnis batak Muslim dan Kristiani dalam meningkatkan harmonisasi beragama di Kabupaten Asahan

3. Langkah langkah yang dilakukan oleh etnis batak Muslim dan batak Kritiani dalam meningkatkan harmonisasi beragama di Kabupaten Asahan

4. Implikasi komunikasi etnis Batak Muslin dan Kristiani dalam meningkatkan harmonisasi beragama di Kabupaten Asahan.

\section{KAJIAN PUSTAKA}

\section{A. Pengertian Komunikasi}

Efendi (1997:5) mengatakan komunikasi adalah topik yang amat sering diperbincangkan bukan hanya dikalangan masyarakat saja melainkan dikalangan publik, sehingga kata komunikasi mengandung begitu banyak arti yang berlainan. Dalam wacana publik sering kali terdengar kalimat yang mengandung kata kata komunikasi seperti "hewan pun berkomunikasi dengan cara mereka masing masing" Komputer adalah alat komunikasi tercanggih, pendeknya istilah komunikasi sedemikian lazim dikalangan kita semua walaupun masing masing orang memberikan istilah secara berlainan. Oleh karena itu kesepakatan memberikan istilah komunikasi merupakan langkah awal untuk memperbaiki pemahaman atas penomena rumit ini.

Efendi (1997:7) juga menjelaskan bahwa komunikasi ataupun communication berasal dari bahasa latin comminis yang berarti "sama" "communico" atau communicare yang berarati "membuat sama" (to make 
common) istilah pertama Communis paling sering disebut dalam asal kata komunikasi yang berarti akar dari kata kata yang mirip. Komunikasi menyarankan bahwasanya sesuatu fikiran, sesuatu makna, suatu pesan yang dianut secara sama. Tetapi defenisi defenisi kontemporer menyarankan bahwa merujuk kepada cara berbagi terhadap hal hal tersebut. Komunikasi ataupun communication berasal dari bahasa latin comminis yang berarti "sama" "communico" atau communicare yang berarati "membuat sama" (to make common) istilah pertama Communis paling sering disebut dalam asal kata komunikasi yang berarti akar dari kata kata yang mirip. Komunikasi menyarankan bahwasanya sesuatu fikiran, sesuatu makna, suatu pesan yang dianut secara sama. Tetapi defenisi defenisi kontemporer menyarankan bahwa merujuk kepada cara berbagi terhadap hal hal tersebut

Pendapat lain mengatakan komunikasi adalah suatu proses penyampaian informasi (pesan, ide, gagasan) dari satu pihak kepada pihak lain. Pada umumnya, komunikasi dilakukan secara lisan atau verbal yang dapat dimengerti oleh kedua belah pihak. apabila tidak ada bahasa verbal yang dapat dimengerti oleh keduanya, komunikasi masih dapat dilakukan dengan menggunakan gerak-gerik badan, menunjukkan sikap tertentu, misalnya tersenyum, menggelengkan kepala, mengangkat bahu. Cara seperti ini disebut komunikasi nonverbal. (Wikipedia.org)

\section{B. Agama dan Masyarakat}

Selain dari lembaga agama yang sudah dikenal terdapat juga banyak juga jenis agama yang tidak tergabung dengan agama samawi dan agama ardhi yang ada disekitar kita yang kerap disebut dengan agama sipil (civil religion). Reusseau lah yang pertama tama mengangkat isu untuk mengambil agama sipil de la religion civil waktu diprancis terjadi sekularisasi besar besaran.

Hampir semua kalangan terpelajar sangat skeptik ${ }^{55}$ dan sinis terhadap agama karena agama dianggap sebagai fungsi sebagai alat penindasan. Berbeda dengan kecendrungan umum ini Rousseau masih, melihat peran positif agama. Dalam pandangannya agama masih mempunyai fungsi sebagai perangkat integratif yang bisa menyatukan masyarakat dengan negara dan dapat pula menyatukan antara suku, ras dan dapat menimbulkan ajaran jaran yang positif. Fungsi ini mirip sekali dengan kepercayaan totem dalam masyarakat primitif seperti yang juga diamati dengan oleh Emile Durkheim. Reusseau juga percaya bahwa setiap bangsa dan negara pasti memiliki tuhan mereka sendiri. 
Tapi intinya Reusseau mengajak orang untuk memikirkan suatau agama yang bisa menyediakan kesetiaan tuggal terhadap negara. Agama sipil ini adalah suatu sistem kepercayaan yang tidak hanya berdasarkan kepercayaan kepada Tuhan, Hari kemudian (hari akhirat) pahala dan dosa tapi juga merasakan suatau kesucian ataupun kesyuhadaan seperti suatu penghormatan suatu bendera negara dan menghormati antar suku dan agama sebagai mana yang dilukiskan oleh Robert N. Bellah.

\section{Hubungan Umat Islam dengan Umat Kristiani}

Hubungan umat Muslim dan umat Kristiani di Indonesia mengalami pasang surut. Dalam sejarah kita mencatat bahwa ada masa dimana mereka hidup secara damai, dan terdapat pula periode dimana berbagai konflik mewarnai hubungan antara kedua komunitas beragama tersebut. Dalam konteks ketidak harmonisan tersebut bagaimana sebenarnya pandangan umat Islam terhadap umat Kristen dan sebaliknya. Dari sudut pandang sebagian umat Islam, beberapa ayat dalam Al quran dianggap memberikan penilaian negatif terhadap umat beragama lain, khususnya Kristen dan Yahudi, baik karena adanya perubahan yang terdapat dalam kitab-kitab suci mereka tahrif dalam hal makna dan tabdil dalam hal kata, ataupun karena upaya mereka untuk menarik umat Islam ke dalam agama mereka

Menurut Hidayat (1998:67) bahwa hal ini diperkuat oleh interaksi sosial antara kedua masyarakat beragama tersebut di mana beragam aktivitas sosial yang dilakukan umat Kristiani seperti penyantunan anak yatim, bantuan bagi masyarakat miskin dan korban bencana, atau pengobatan gratis dapat ditafsirkan sebagai upaya untuk menarik umat Islam ke dalam agama mereka (Kristen) yang kerap terjadi akhir-akhir ini. Selain itu Ridwan (2013:78) mengatakan dalam bidang pendidikan, sekolah-sekolah Kristen sangat favorit seringkali dianggap sebagai salah satu jalur yang cukup efektif untuk menarik anak-anak Muslim kedalam agama Kristen. Pada kenyataan yang terjadi, bagi sebagian masyarakat Muslim, Kristenisasi tersebut bukanlah dianggap sebagai isu, namun merupakan masalah yang terjadi yang mengganggu keharmonisan hubungan umat Muslim dengan umat Kristiani. Sebaliknya, sebagian umat Kristiani memahami bahwa agama mereka, sebagaimana agama dakwah yang lain, menegaskan perlunya penyebaran jalan keselamatan yang dibawa oleh Yesus Kristus. 


\section{Indikator Harmonisasi Beragama}

Sikap saling menghormati (toleransi), Toleransi beragama merupakan kelanjutan dari sikap pengakuan para penganut agama terhadap agama yang ada di luar keyakinanya. Dialog intensif yang terus terjalin antar umat beragama yang memperlakukan semua agama sejajar dalam mengekspresikan keberagamaannya mendorong keharmonisan yang relatif sejati. Kerja sama lembaga-lembaga agama dalam menghadapi berbagai persoalan keagamaan merupakan kondisi kehidupan umat beragama yang diharapkan. Kondisi Ideal keharmonisan umat beragama adalah, sikap saling bekerja sama seperti saling bekerja sama antar penganut dan kelompok agama merupakan puncak dari sikap saling mengakui dan saling menghormati antar pemeluk agama. Keharmonisan kehidupan umat beragama sejatinya akan terlihat dari adanya persamaan keprihatinan dan kepentingan yang diwujudkan dalam tujuan dan aktifitas kolektif yang bermanfaat bagi kehidupan beragama. Kerjasama sebagai aktualisasi dari keharmonisan umat beragama tentu sangat tergantung dari kemauan umat beragama itu sendiri

Sebagai indikator untuk melihat keharmonisan beragama dalam penelitian ini ada lima indikator yang bisa dijadikan ukuran menurut jurnal FKUB yaitu:

1. Berkembangnya pemahaman agama yang moderat (selalu menghindarkan perilaku atau pengungkapan yang ekstrem, berkecenderungan ke arah dimensi atau jalan tengah), seperti pemahaman agama ini sangat mendukung lahirnya toleransi dan kerja sama tanpa mengusik sedikitpun keyakinan masing-masing. Setiap individu dan kelompok agama memiliki hak yang sama untuk hidup dan mengamalkan nilai-nilai yang diyakini kebenarannya.

2. Meningkatnya pemahaman dan pengamalan agama, seperti kehidupan umat beragama yang harmonis dapat mendorong peningkatan pemahaman dan pengamalan ajaran agama, karena semua pemeluk agama mempunyai keleluasaan menjalankan ajaran agamanya dengan sebaikbaiknya tanpa ada gangguan. Dengan menguatnya keharmonisan umat beragama juga akan terjadi peningkatan pemahaman yang komprehensif tidak parsial, radikal dan simbolis tapi di implementasikan dalam kehidupan. 
3. Berkurangnya konflik bernuansa sosial keagamaan dengan kerukunan umat beragama yang baik akan berdampak pada berkurangnya konflik bernuansa sosial keagamaan. Indikator yang keempat, berkembangnya kerjasama umat beragama dalam kehidupan sosial seperti kehidupan umat beragama yang harmonis dapat diukur dari terbangunnya kerjasama sosial diantara kelompok-kelompok agama yang ada

4. Sikap saling bekerja sama seperti saling bekerja sama antar penganut dan kelompok agama merupakan puncak dari sikap saling mengakui dan saling menghormati antar pemeluk agama. Keharmonisan kehidupan umat beragama yang sejati akan terlihat dari adanya persamaan keprihatinan dan kepentingan yang diwujudkan dalam tujuan dan aktifitas kolektif yang bermanfaat bagi kehidupan beragama. Kerjasama sebagai aktualisasi dari keharmonisan umat beragama tentu sangat tergantung dari kemauan umat beragama itu sendiri.

5. Perlakuan yang adil dalam berbagai kehidupan bermasyarakat, berbangsa dan bernegara, seperti kehidupan umat beragama yang harmonis harus terindikasikan dengan berkurangnya kecemburuan sosial, perlakuan yang adil dalam kehidupan bermasyarakat, berbangsa dan bernegara sangat erat hubungannya dengan terwujudnya keharmonisan umat beragama ${ }^{61}$

Hubungan keharmonisan, integrasi sosial dan kesatuan bangsa pada akhirnya adalah terwujudnya peningkatan rasa aman dan damai, penguatan ketahanan sosial masyarakat, penguatan wawasan kebangsaan, peningkatan harkat dan martabat bangsa dan peningkatan suasana kondusif untuk pembangunan. Salah satu agenda besar bangsa Indonesia dewasa ini dan kedepan adalah mengembangkan sikap dan perilaku sosial yang mendukung bagi pemaknaan keharmonisan kehidupan umat beragama dalam koridor integrasi nasional yang dicita-citakan bersama. Sikap dan perilaku sosial itu haruslah dibangun dan dikembangkan atas dasar paradigma kerukunan umat beragama dalam rangka menjaga persatuan dan kesatuan bangsa.

\section{METODE PENELITIAN}

\section{A. Lokasi Penelitian}

Penelitian ini dilaksanakan di Kabupaten Asahan Provinsi Sumatera Utara. Asahan berdiri tahun 1630 di wilayah yang sekarang menjadi Kota Tanjung Balai, Kabupaten Asahan, Kabupaten Batubara, Kabupaten Labuhanbatu Utara, Kabupaten Labuhanbatu, dan Kabupaten Labuhanbatu Selatan. Kesultanan ini ditundukkan Belanda pada tahun 1865. Kerajaan ini melebur ke dalam negara Indonesia pada tahun 1946. Di bawah pemerintahan

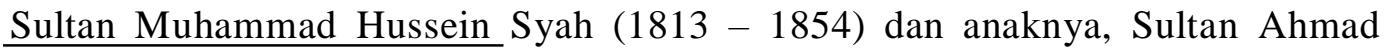
Syah, Asahan merupakan kerajaan yang disegani di daerah antara Serdang dan 
Siak dan mempunyai pengaruh besar di Batu Bara, Bilah dan Panai.

\section{B. Subjek Penelitian}

Untuk memperoleh data mengenai strategi penguatan Pola Komunikasi yang dilakukan oleh etnis batak Muslim dan Kristiani dalam meningkatkan harmonisasi beragama di Kabupaten Asahan, peneliti membutuhkan informan penelitian yaitu pemuka agama Islam dan Kristen lembaga lembaga yang terkait seperti FKUB (Forum Kerukunan Umat Beragama) dan organisasi gereja Kristen seperti Huria Kristen Batak Protestan (HKBP) dan Gereja Pentakosta Indonesia (GPI) dan pendeta beserta jemaat lainnya dan beberapa responden penelitian yang cukup berkompeten yang khususnya bersuku batak baik itu Muslim maupun Kristiani serta informan yang cukup berkompeten dalam penelitian ini, dan beberapa kecamatan yang dikategorikan banyaknya penduduk suku batak yang beragama Kristen, banyaknya penduduk yang bersuku batak yang beragama Islam oleh sebab itu maka penetapan mereka sebagai informan dalam penelitian ini tentunya sangat beralasan sekali. Adapun informan dalam penelitian ini terdiri dari Ketua dan sekretaris FKUB, Mewakili setiap Desa dan Kelurahan pemuka Agama Islam, Mewakili Setiap Desa dan Kelurahan Pemuka Agama Kristen, dan Penduduk yang menjadi responden yang mewakili Desa dan Kelurahan.

\section{Pendekatan Penelitian}

Penelitian ini adalah penelitian lapangan (field research) yang dilakukan dengan pendekatan kualitatif. Seperti yang disebutkan oleh Bambang Rudito dkk (2008:78) "pendekatan kualitatif memusatkan perhatian pada prinsip-prinsip umum yang mendasari perwujudan satuan-satuan gejala yang ada dalam kehidupan sosial”. Menurut Lexy J. Moleong (2007:6) mengatakan penelitian dengan pendekatan kualitatif adalah penelitian yang bermaksud untuk memahami fenomena tentang apa yang dialami oleh subjek penelitian misalnya perilaku, persepsi, motivasi, tindakan, dan lain-lain secara holistik dan dengan cara deskripsi dalam bentuk kata-kata dan bahasa, pada suatu konteks khusus yang alamiah dan dengan memanfaatkan berbagai metode alamiah.

Rudito dkk (2008:79) mengatakan dalam pendekatan kualitatif yang menjadi sasaran kajian/penelitian adalah kehidupan sosial atau masyarakat sebagai satu kesatuan, atau sebuah kesatuan yang menyeluruh. Penelitian yang dilakukan terarah pada disiplin ilmu komunikasi dalam batasan yang sangat sederhana. Dalam penelitian ini berupaya melakukan analisa untuk merumuskan pola komunikasi yang efektif untuk meningkatkan kerukunan harmonisasi beragama sesame etnis batak. 


\section{Teknik Pengumpulan Data}

Menurut Kusnadi (2008:4-6) pengumpulan data pada penelitian ini dilakukan melalui tiga cara, yaitu:

a. Wawancara mendalam merupakan teknik pengumpulan data utama yang diperoleh melalui wawancara tidak terstruktur secara mendalam kepada subjek penelitian terkait, baik yang termasuk pada kategori sumber data primer maupun yang termasuk pada kategori sumber data skunder.

b. Observasi. Observasi pada penelitian ini dijadikan sebagai salah satu teknik pengumpulan data pendukung. Obeservasi dimaksudkan sebagai upaya untuk meninjau langsung situasi pada wilayah penelitian guna mengkonfrontir hasil wawancara terhadap kenyataan yang ditemukan di lapangan.

c. Studi literature/dokumen. Studi literature/dokumen merupakan teknik pengumpul data pendukung dengan cara menelaah literatur dari berbagai sumber yang memiliki kaitan erat dengan permasalahan yang sedang diteliti dan dokumen-dokumen terkait yang dimiliki lembaga agamaagama bersangkutan

\section{E. Teknik Analisa Data}

Analisis data menurut Moloeng (2007:10) ialah proses mengorganisasian dan mengurutkan data kedalam pola, kategori dan satuan uraian dasar sehingga dapat ditemukan tema dan dapat dirumuskan hipotesis kerja seperti yang disarankan oleh data. ${ }^{66}$

\section{HASIL PENELITIAN DAN PEMBAHASAN}

\section{A. Pola Komunikasi Antar Batak Muslim Dan Batak Kristiani Dalam Meningkatkan Harmonisasi Beragama di Kabupaten Asahan}

Masyarakat pedesaan khususnya di Kabupaten Asahan pada umumnya banyak sekali menerima informasi dari dari masyarakat perkotaan dikarenakan akses yang diterima lebih dahulu masyarakat perkotaan yang menerima akses informasi tersebut dari pada masyarakat desa. Masyarakat desa pada umumnya banyak sekali yang mempunyai sangat ortodokis (menganut pemikiran yang diwarisi orang tua mereka dahulu) oleh karena itu pemahaman tentang agama masih mengikuti panduan ajaran yang terdahulu namun masik mengikuti faham panatisme yang tidak sedikitpun membuka akses sosial pada mereka yang beragama lain walaupun satu etnis namun tidak dipungkiri juga ada juga desa yang menerapkan keharmonisan tersebut seperti yang disebutkan diatas namun 
mereka mengikuti atura aturan yang telah disepakati mereka bersama.

Vol.2, No.2, November Tahun 2019

Komunikasi adalah hal yang sangat utama yang harus diperbaiki lebih dahulu karena dari situlah dapat menyampaikan pesan dengan baik tanpa ada komunikasi maka tidak akan pernah terjalinnya harmonisasi dari aspek manapun. Yang menjadi pertanyaan dalam pembahasan dalam sub bab ini bagaimana membangun dan merumuskan pola komunikasi antar suku batak Muslim dan suku batak Kristiani untuk meningkatkan harmonisasi beragama? berikut ini akan dipetakan bagaiman pola komunikasi yang akan dirumuskan.

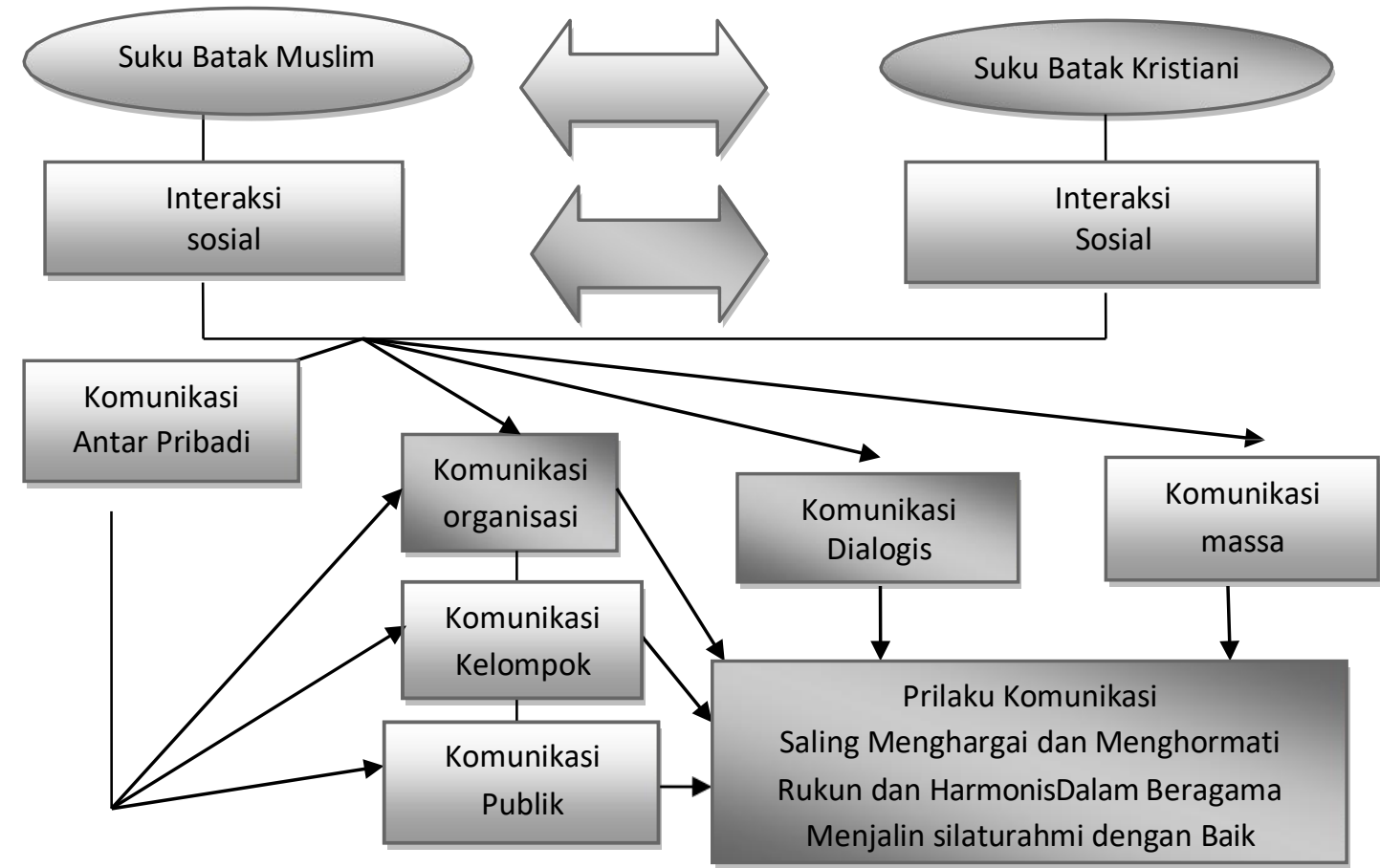

Gambar :.1. Peta Konsep Pola Komunikasi Antar Etnis Batak di Kab. Asahan

Peta Konsep tentang pola Komunikasi yang akan dirumuskan untuk meningkatkan harmonisasi beragama antar sesama etnis batak, tidak lain adalah beberapa pola komunikasi yaitu :

\section{Pola Komunikasi Antar Pribadi}

Komunikasi antar pribadi terjadi dalam konteks satu komunikator dengan satu komunikan (komunikasi diadik, dua orang) satu komunikator dengan dua komunikan (komunikasi triadik, tiga orang) lebih dari tiga orang biasanya dianggap komunikasi kelompok. Yang artinya bahwa setiap etnis batak Muslim dan kristiani dalam menajalan kehidupan sosial sehari hari harus selalu berdampingan dan menjaga silaturahmi dengan baik dan masalah ajaran agama itu tergantung kepada pribadi masing masing.

\section{Komunikasi Dialogis Sebagai Kontrol Sosial di Kabupaten Asahan}

Kemajemukan agama merupakan kenyataan historis dan empiris yang tidak dapat dibantah lagi. Pluralitas yang terjadi dikabupaten Asahan tersebut menghadirkan potensi konflik sosial diantara pemeluknya. Sejarah telah mencatat tentang sering munculnya 
konflik tersebut, baik dalam level intern atau antar batak Muslim dan batak Kritiani apalagi perbedaan berkeyakinan yang dipicu dengan panatisme agama yang berlebihan. Konflik yang terjadi pada masyarakat yang beretnis batak Muslim dan batak Kritiani Khususnya di Kabupaten Asahan tidak dapat dihilangkan, karena beranggapan bahwa dalam masyarakat yang didalamnya ada perbedaan agama agama yang dianggap Sakral tidak akan terjadi konflik, apalagi berusaha untuk menghilangkannya adalah sama artinya menafikan karakter masyarakat modern.

Konflik sosial antar etnis batak Muslim dan Batak Kristiani tersebut hanya dapat dikendalikan agar menjadi potensi positif bagi pengembangan kehidupan masyarakat. Salah satu model untuk mengendalikan konflik antar etnis batak Muslim dan batak Kristiani adalah melalui pembentukan jaringan komunikasi sosial dan kerjasama lembaga lembaga lintas agama seperti FKUB yang dibawah naungan KEMENAG, dan keberagaman merupakan perilaku yang bersumber langsung atau tidak langsung kepada kitab suci.

\section{B. Hambatan Yang Ditemukan Oleh Etnis Batak Muslim Dan Kristiani Dalam Meningkatkan Harmonisasi Beragama Di Kabupaten Asahan}

Bercerita tentang hambatan hambatan yang terjadi dalam meningkatkan harmonisasi beragama di Kabupaten Asahan tidak terlepas dari kelompok kelompok dan kesukuan dan keberagama pemahaman tentang agama. Ketika kepentingan antar kelompok yang berbeda itu bertentangan antara satu dengan yang lain, maka memicu

akan sulitnya untuk mewujudkan keharmonisan dalam beragama dan berkeyakinan. Berikut beberapa hambatan yang ditemukan:

1. Meningkatnya konservatisme keagamaan

Koservatisme adalah faham melestarikan; menjaga, memelihara, dan mengamalkan. Sebagian pihak konservatif berusaha melestarikan status quo, sementara yang lainnya berusaha kembali kepada nilai-nilai dari zaman yang lampau begitu juga yang terjadi di antara etnis batak Muslim dan batak Kristiani yang terjadi di Kabupaten Asahan

2. Fanatisme yang berlebihan para pemeluk agama

Perbedaan antar suku batak Muslim dan suku batak Keristiani sudah lumrah karena setiap ajaran agama yang berbeda walaupun satu suku. Kondisi kerukunan hidup beragama akan berubah menjadi konflik jika faktor-faktor penyebab terjadinya permasalahan tidak diperhatikan oleh berbagai kelompok umat beragama maupun pemerintah.

3. Ketidak Adilan dan kesenjangan sosial antara mayoritas dan minoritas Kesenjangan sosial dan ketidakadilan menjadi hambatan yang sangat riskan dalam meningkatkan harmonisasi beragama. keharmonisan tidak bisa 
berlangsung sungguh-sungguh jika tidak adanya keadilan dan adanya

kesenjangan sosial maka komunikasi akan gagal, mengutamakan banyak nya penganut agama antar suku batak Muslim dan Kristiani tersebut sehingga masing-masing kelompok penganut agama tersebut merasa dikucilkan dan tidak adanya singkronisasi dalam aspek sosial, ekonomi dan politik.

4. Budaya keagamaan yang tidak bisa diterima antara satu sama lain Bercerita tentang perbedaan budaya yang dilakukan antar agama yaitu suku batak Muslim dan Kristiani dikabupaten Asahan sungguh banyak terjadi terutama dari segi binatang peliharaan contohnya dari kebiasaan dan masyarakat batak Muslim menganggap bahwa batak Kristiani adalah suku batak yang paling jorok dari pada penganut agama Kristiani yang lain Tiong hoa misalnya demikian pula sebaliknyaBercerita tentang perbedaan budaya yang dilakukan antar agama yaitu suku batak Muslim dan Kristiani dikabupaten Asahan sungguh banyak terjadi terutama dari segi binatang peliharaan contohnya dari kebiasaan dan masyarakat batak Muslim menganggap bahwa batak Kristiani adalah suku batak yang paling jorok dari pada penganut agama Kristiani yang lain Tiong hoa misalnya demikian pula sebaliknya.

\section{Langkah Langkah Yang Dilakukan Oleh Batak Muslim Dan Batak Kristiani dalam Meningkatkan Harmonisasi Beragam Di Kabupaten Asahan}

Langakah-langkah dalam penerapan pola komunikasi antar batak Muslim dan batak Kristiani dikabupaten asahan menurut data Depag RI (1997:8-20) dapat terwujud apabila beberapa poin tersebut dapat dilaksanakan secara maksimal yaitu:

1. Saling menghormati dan menghargai sesama penganut agama Saling menghormati dan menghargai sesama penganut agama merupakan salah satu pilar utama dalam memelihara persatuan dan kedaulatan. keharmonisan sering diartikan sebagai kondisi hidup dan kehidupan yang mencerminkan suasana damai, tertib, tentram, sejahtera, hormat menghormati, harga menghargai, tenggang rasa, gotong royong sesuai dengan ajaran agama masing masing dan kepribadian pancasila.

2. Menumbuhkan Komunikasi dan Kesadaran Rukun dan Toleran antar batak Muslim dan Batak Kristiani Melalui Pendidikan

Setelah menganalisis sebagaian diantara penyebab terjadinya ketidak harmonisan antar batak Muslim dan batak Kristiani di Kabupaten Asahan, dan kehidupan sosial tentang toleransi sebagaimana dikemukakan di atas, maka bagi umat beragama, khususnya antar batak Muslim dan batak Kristiani berkewajiban, baik secara moral maupun sosial, untuk melakukan tindakan-tindakan toleransi. 
3. Sikap Saling Menghargai Hak Antar Batak Muslim Dan Batak Kristiani Dalam Menjalani Kehidupan Beragama Sehari Hari

Setiap umat beragama harus atau wajib memupuk, melestarikan dan meningkatkan keyakinannya. Dengan mempertebal keyakinan maka setiap umat beragama terkhusus suku batak muslim dan batak kristiani akan lebih saling pengertian sehingga perasaan takut dan curiga semakin hari bersamaan dengan meningkatkan taqwa pada ajaran agama mereka masing masing, dan perasaan curiga dapat yang menimbulkan deskriminasi terhadap agama yang mereka anut tersebut dapat dihilangkan.

4. Sering Mengadakan Dialog Antar Etnis Batak Muslim Dan Kristiani Tersebut Dalam Hal Harmonisasi Beragama Dikabupaten Asahan

Dengan cara berdialog merupakan salah satu cara yang diambil guna mendekatkan lebih dahulu, agar umat mereka memahami dan berusaha saling mengenal antara pihak yang satu dengan yang lain. Tujuan dialog adalah sesuatu yang positif bukanlah hal yang negatif yaitu memberi informasi dan nilai-nilai yang dimiliki, lalu meminta pihak lain mengambil keputusan yang dapat dipertanggungjawabkan.

\section{Implikasi Komunikasi Antar Batak Muslimdan Batak Kritiani Dalam Meningkatkan Harmonisasi Beraga di Kabupaten Asahan}

Implikasi komunikasi antar batak muslim dan batak Kristiani berarti efek yang terjadi apabila penerapan pola komunikasi yang terjadi dengan baik adalah:

1. Saling menjalin Keakraban Melalui FKUB kabupaten Asahan hendaknya sering mengadakan dialog dialog langsung dan sering untuk duduk bersama dalam membahas tentang kerukunan untuk menuju harmonisanya anatar batak Muslim dan Batak Kristiani yang ada dikabupaten Asahan seperti halnya dialog dialog antar pemuka agama Islam dan Kristen yang berseku batak yang bertujuan untuk menjalin hubungan baik antar etnis batak Muslim dan Kristiani dan melibatkan juga penganut agama hindu Budha dan Konghucu.

2. Saling Bekerja Sama Antara Satu Dengan Yang Lain.

Menjalin kerja sama antar etnis batak Mulim dan batak Kristiani sungguh jarang sekali terjadi karena umat Muslim dan umat Kristiani sama sama saling tertutup dalam dan hampir tidak membuka akses komunikasi untuk menjalin keakraban satu sama lain

3. Tidak Adalagi upaya kristenisasi dan islamisasi

Kristenisasi dan Islamisasi adalah suatu problem yang cukup memicu terjadinya konflik sosial antar hubungan komunitas batak Muslim dan batak Kritiani yang 
ada dikabupan Asahan. karena mengingat kesakralan agama tersebut oleh karenanya yang satu dengan yang lain merasa emosional yang meledak apabila terjadi kristenisasi dan islamisasi

\section{PENUTUP}

Berdasarkan analisis data hasil penelitian yang telah dipaparkan pada bab-bab sebelumnya, dapat diambil beberapa simpulan sebagai berikut:

1. Pola komunikasi antar batak Muslim dengan batak Kristiani di Kabupaten Asahan untuk meningkatkan harmonisasi beragama dengan baik adalah dengan pola komunikasi interpersonal, pola komunikasi dialogis, pola komunikasi publik, pola komunikasi organisasi yang dimana pola komunikasi tersebut diatas dapat menghasilkan prilaku komunikasi yaitu saling rukun saling menghargai, saling bekerja sama dalam aspek sosial, dan saling menjalin keakraban antara etnis

batak Muslim dan batak Kristiani tersebut dalam meningkat harmonisasi beragama.

2. Hambatan hambatan yang terjadi antar suku batak Muslim dan batak Kristiani di Kabupaten Asahan yaitu meningkatnya konsertvatisme keagamaan panatisme yang berlebihan pada pemeluk agama yang menimbulkan tidak ada ruang untuk menerima agama lain untuk hidup berdampingan serta ketidak adilan, kesenjangan sosial antara mayoritas dan minoritas pemeluk agama serta budaya agama yang tidak bisa diterima antara satu dengan yang lain.

3. Langkah langkah yang dilakukan oleh suku batak Muslim dan batak Kristiani dalam meningkatkan harmonisasi beragama adalah bagaimana saliang menghormati dan menghargai sesame pemeluk agama, menumbuhkan komunikasi dan kesadaran rukun dan toleran antar batak Muslim dan batak Kristiani melalui pendidikan, sikap saling menghargai hak antar batak Muslim dan batak Kristiani dalam menjalani kehidupan beragama sehari hari, berfikir positif, sering melakukan dialog antar batak Muslim dan batak Kristiani dalam hal meningkatkan harmonisasi beragama.

4. Implikasi komunikasi antar batak Muslim dan Batak Kristiani dalam meningkatkan harmonisasi beragama adalah saling menjalin keakraban, saling bekerja sama antar satu dengan yang lain, dan tidak adalagi upaya Kristenisasi dan Islamisasi.

\section{DAFTAR PUSTAKA}

Abdullah, HM.Amin. 1999. Relevansi Studi Agama di Era Pluralisme Agama, dalam Muhammad Sabri, Keberagamaan Yang Saling Menyapa, Perspektif Filsafat Perenial. Yogyakarta:Ittaqa Press

Agus. 2001. Teori dan Paradigma penelitian Sosial Agus Salim.Yogyakarta: 
JISA: Jurnal Ilmiah Sosioologi Agama

Prodi Sosiologi Agama Fakultas Ilmu Sosial UIN SU Medan

Tiara Wacana

Vol.2, No.2, November Tahun 2019

Alwi, Hasan. 1995. Kamus Besar Bahasa Indonesia Edisi.II. Jakarta: Balai Pustaka

Arifin, Anwar. 1984. Strategi Komunikasi: Suatu Pengantar Ringkas. Bandung: Armico

Azra, Azyumardi. 1991. Bingkai Teologi Kerukunan: Perspektif Islam Dalam Konteks Berdialog Di Indonesia: Pengalaman Islam. Jakarta: Paramadina

Banawiratma J. 1993. Bersama Saudara-Saudari Beriman Lain. dalam Eka

Berner, Eric. 1964. Games People Play. Landon: Cambridge Univercity Press

Burhan, Bungin. 2001. MetodologiPenelitian Sosial, Format-format kuantitatif dan Kualitatif. Surabaya: Airlangga University Press

Cangara, Havied. 2002. Pengantar Ilmu Komunikasi. Jakarta: Raja Grafindo Persada

Cassata, Mary B dan Mollefi Kasante. 1979. Communication Principel and Practices.

Darmaputra, Dialog: Kritik dan Identitas Agama Yogyakarta: Dian/Interfidei

Daymon, Cristin, dan Holloway, Immy. 2008. Metode-metode Riset Kualitatif dalam Public Relations dan Marketing Communication. Yogyakarta: Bentang

Depag RI. 1997. Bingkai Teologi Kerukunan Hidup Umat Beragama Di Indonesia. Jakarta: Badan Penelitian dan Pengembangan Agama Proyek Peningkatan Kerukunan Umat Beragama di Indonesia

Efendi, Onong Uchjana. 1997. Ilmu Komunikasi Teori dan Praktek. Bandung: remaja Rosdakarya

Gozali, Abdurrahim. 1988. Agama dan Kearifan dalam Masyarakat. Bandung: Pustaka hidayah

Harjana, Andre. 1993. Perbandingan Pola Strategi Komunikasi Penunjang Proses Industrialisasi. Jurnal ISKI: Oktober

Hendropuspito. 2000. Sosiologi Agama. Yogyakarta; Kanisius

Hidayat, Komaruddin. 1998. Agama dan Wacana Agama dalam Dialog Bebas Konflik. Bandung: Pustaka Hidayah, cet. I

Joseph, Devito. 1997. Komunikasi Antar Manusia: Kuliah Dasar. Jakarta: Profesional Books

Liliweri, Alo. 1991. Komunikasi Antar Pribadi. Bandung: PT. Citra Aditya Bhakti

Lubis M. Ridwan. 2013. Sosiologi Agama. Jakarta: Remadja Rosdakarya 
JISA: Jurnal Ilmiah Sosioologi Agama

Prodi Sosiologi Agama Fakultas Ilmu Sosial UIN SU Medan

Vol.2, No.2, November Tahun 2019

Mas'ud, Abd Rahman Dan A. Salim Rohana. 2012. Kompilasi Kebijakan Dan Peraturan Perundang-Undangan Kerukunan Umat Beragama. Jakarta: Puslitbang Kehidupan Keagamaan Kementerian Agama RI

Moleong J. Lexy. 2006. Metodologi Penelitian Kualitatif. Bandung: Remadja Rosdakarya

Muhadjir, Noeng. 1989. Metodologi Penelitian Kualitatif. Jakarta: Gramedia Media Utama

Mulyana, Deddy. 2005. Ilmu Komunikasi: Teori dan Praktik. Jakarta: Remadja Rosdakarya

Newcomb. 1985. Psikologi Sosial. Bandung: Diponogoro, 1985

A. Oberschall. 1978. Theories of Social Conflict. Annual Review of Sociology. Vol. 4

Rahman, Fazhur. 1984. Islam Terjemahan Ahsin Muhammad. Bandung: Pustaka

Ritzer, George. 2011. Sosiologi Ilmu Pengetahuan Berparadigma Ganda. Jakarta: Rajawali Pres

Rudito, Bambang dan Melia Famiola. 2008. Social Mapping (Metode Pemetaan Sosial): Teknik Memahami Suatu Masyarakat atau Komuniti. Bandung: Rekayasa Sains

Sabri Muhammad. 1999. Keberagamaan Yang Saling Menyapa. Perspektif Filsafat Perenial. Yogyakarta: Ittaqa Press

Scharf, Betty R.. 2004. Sosiologi Agama. Jakarta; Prenada Media

Sihab, Alwi. 2009. Islam Insklup Terbuka dalam Bergama. Bandung: Mizan Cet,1 1991. Memahami Peran Komunikasi Massa Dalam Masyarakat Bandung: Citra Aditya Bakti

Tubbs, Stewart L Moss. 2005. Human Communication: diterjemahkan oleh Sylvia dalam Konteks-Konteks Komunikasi,. Bandung: PT Remaja Rosdakarya

Wiraman, IB. 2013. Teori Sosial dalam Tiga Paradigma. Jakarta: Kencana Media Group

Wiryanto. 2005. Pengantar Ilmu Komunikasi. Jakarta: Gramedia Widiasarana Indonesia 